\title{
REFERENCES
}

Bladuri.-Amer. Jl. Ophthal., Vol. X, pp. 194-195, 1927.

Böwer.-Klin. Monatsbl.f. Augenheilk., Vol. LXXXVIII, pp. 329-332, 1932.

Cange.-Arch. d'Ophtal., Vol. XLVI, pp. 385-395 and 734-737, 1929.

Cawston.-Brit. Med. Jl., p. 855, December 4, 1923.

Coloin, Paton and Dawes.-Med. Jl. Australia, pp. 685-686, June 3, 1933.

Crebbin.-Amer. Jl. Ophthal., Vol. XII, pp. 384-387, 1929.

Dimitry.-Amer. Jl. Trop. Med., Vol. XI, pp. 65-69, 1931.

Elliot.- Tropical Ophthalmology. Oxford University Press, p. 438, $1920 . \quad$ Arch. d'Ophtal., Vol. XLIX, pp. 734-737, 1929.

Hoffman.-Jl. Trop. Med., Vol. XXXII, pp. 328-330, 1929.

- Ji. Trop. Med., Vol. XXXIII, pp. 233-236, 1930.

Huizenga.-Jl. Ophthal., Otol. and Laryngol., Vol. XXXI, pp. 159-161, 1927. China Med.Jl., Vol. XLI, pp. 153-156, 1927.

Horton.-Amer.Jl. Ophthal., Vol. X, pp. 194-195, 1927.

Janson.-Klin. Monatsbl. f. Augenheilk., Vol. XCI, pp. 213-235, 1933.

Kirwan.- Transactions of Seventh Congress Far East Association of Tropical Medicine. Vol I, 1927.

Larsson.-Acta Ophthal., Vol. VI, pp. 344-349, 1928.

Levitt.-New York Med. Jl., Vol. CXVI, p. 376, 1922.

Manson-Bahr. - Tropical diseases. 1925.

Minder.-Klin. Monatsbl. f. Augenheilk., Vol. LXXXII, pp. 36-39, 1929.

Neame.-Proc. Roy. Soc. Med., Vol. XIV, p. 16, 1921.

Peter.-Arch. of Ophthal., Vol. LIII, p. 258, 1924.

Pfingst.-Amer. Jl. Ophthal., Vol. IX, p. 195, 1926.

Pillat.-A rch. Ophthal., Vol. III, pp. 306-317, 1930.

Pinkerton.-Laryngoscope. Vol. XLIII, pp. 991-1001, 1933.

Arch. Ophthal., Vol. XLIII, pp. 42-51, 1927.

Rogers.-Amer. Jl. Ophthal., Vol. X, pp. 503-506, 1927.

Rogers and Muir.-Leprosy. New York.

Trantas.-Arch. d'Ophtal., p. 193, April, 1912.

Treacher Collins.-Trans. Ophthal. Soc. U.K., Vol. XXIX, p. 223, 1909.

Wood.-Brit. Jl. Ophthal., Vol. IX, p. 1, 1925.

Yudkin.-Amer. Jl. Ophthal., Vol. I, p. 303, 1918.

\section{THE INHERITANCE OF OPAQUE NERVE FIBRES IN THE RETINA (PAPILLA LEPORINA)}

\author{
BY \\ E. A. Cockayne
}

LONDON

OPAQUE nerve fibres in the retina, though they are abnormal in man, occur as a normal condition in some mammals. Johnson says that they are present in some of the rodents, more particularly in the Leporidae and in some marsupials, such as Perameles lagotis. In the rabbit they form a transverse band stretching right across the retina, but do not become visible until ten days after birth, when medullation has taken place. Johnson gives beautiful coloured plates of the fundi of the rabbit and $P$. lagotis, the rabbit-eared perameles. Waardenburg states that they are present in the ox and dog, but this is not shown in 
Johnson's plates nor is it mentioned in his text. In all mammals, in which they occur normally, they start at the disc and follow the course of the main arteries, and this is almost invariably the case in man also.

Medullated nerve fibres in man normally stop at the lamina cribrosa, and according to Berliner, when they are present in the retina, they are not continued through the lamina, but commence again independently in the retina. Medullation takes place from the centre towards the periphery and is completed last in the optic nerve. At birth the nerve fibres are not yet medullated either in the optic nerve or in the retina, and opaque nerve fibres are not seen until some months after birth. Berliner believes that myelin is laid down by the oligodendroglia, which in normal people is not present in the retina, and suggests that its presence in this unusual situation is the cause of opaque nerve fibres, but he gives no satisfactory proof of this.

They cause no symptoms in man, but the size of the blind spot may be increased, though not so much as might be expected from their extent, because in a thin layer they are transparent to light.

The defect is not a very rare one. In a table compiled by Kisô from various European sources they were found in $35 \tau$ people out of 628,144 and in one compiled from Japanese sources in 9 out of 13,622 , but these figures are not a true index of the incidence, because all were not examined with the ophthalmoscope. The incidence, however, cannot be lower than 1 in 1,759 in Europeans and 1 in 1,513 in Japanese, and may be a good deal higher. Kisô found the condition in 1 out of 659 , in whom the fundi were described.

In most people they form a small patch spreading out from one quadrant of the disc, and seldom arise from its whole circumference, and only in 14 to 18 per cent. are they present in both eyes. According to Kölliker of 156 cases, 62 per cent. were in males and 38 per cent. in females, and the figures given by Terwelp are similar, for of 122 people, 66 per cent. were males and 34 per cent. females.

Opaque nerve fibres in the retina have been found in association with the following abnormalities-with a persistent hyaloid artery by Blascheck, Mayerweg, Bliedung, Fischer, and Terwelp, Fischer's patient having neurofibromatosis, and Terwelp's a polar cataract also; with congenital cataract by Kölliker, Menacho, Takada, and Tereschkowitsch, a coloboma of the optic nerve being present also in the last case, with a coloboma of the macula by v. Duyse and Clausen, Clausen's patient having a son with a similar coloboma, but no opaque nerve fibres; with a 
coloboma of the choroid by Derby; with a coloboma of the choroid and iris by Schmidt-Rimpler and Hilbert; with a coloboma of the iris and an accessory pupil below in each eye by Strzeminski, and with a persistent pupillary membrane by Fleming, Assicot, Kohda, and Kraupa, Kraupa's patient having oxycephaly, imbecility, and myopia, 11D., in both eyes. I have seen a streak of opaque nerve fibres running from the upper part of the right disc along one of the main arteries in a boy of six with oxycephaly. Mayerweg has recorded the presence of opaque nerve fibres, a large angioma, and 10D. myopia in the same eye, and Eversbusch an abnormally developed disc with a large central scotoma, and Kono connective tissue at the disc and $20 \mathrm{D}$. myopia in both eyes. They have also been found several times in association with an abnormal shape of the disc or with pigmentation of the disc. In most of these cases the opaque nerve fibres were extensive. It is, however, very doubtful whether their association with such developmental anomalies is more than a coincidence. Opaque nerve fibres are sufficiently common for such coincidences to happen, and not only are they more likely to be detected, when another more important defect is present, but are much more likely to be placed on record.

There may be a closer relation between myopia and opaque nerve fibres, for when these are unilateral myopia may be confined to the affected eye or may be of much greater degree in it. Berg and Degner found myopia above 5D. in 25 out of 40 patients with opaque nerve fibres and Kölliker says that 47.9 per cent. are myopic, but other authors have found myopia rather uncommon in these cases. This difference of opinion seems to be due to the fact that those, in whom the condition is highly developed, are frequently myopic, while those in whom it is only slight, are no more prone to myopia than normal people.

Fischer found opaque nerve fibres in the retina in 4 out of 12 people with neurofibromatosis, and in 4 others with pigmented naevi, whom he considers were suffering from a slighter form of the same disease. He also points out that they have been found several times in imbeciles and that they are much commoner in people suffering from psychoses than in normal individuals. He thinks that the presence of opaque nerve fibres in such cases is a sign of a widespread developmental defect of the central nervous system, and that even in apparently normal people it may be an indication of a more trifling defect in this situation. Before his conclusions can be accepted we must know the incidence of opaque nerve fibres in a much longer series of cases of neurofibromatosis, and its exact incidence amongst the general population.

There are few records of the inheritance of the condition. Mauthner records it in two sisters, and Meyer-Riemloh in a 
mother and in her daughter, who also suffered from epilepsy and Leber's optic atrophy. The only pedigree of any length is that of a Japanese family published by Kisô, and reproduced by Kurzes Handbuch der Ophthalmologie, Komai, and Waardenburg. In this six individuals were affected in two generations and, with three exceptions, the descent was direct. In one of these a normal female transmitted it to her two surviving daughters, in another a normal female transmitted it to one son, four other sons and daughters being unaffected, and in the third a normal female transmitted it to a son, two other sons and a daughter being normal, and one son and four daughters not examined. Of the six affected three were males, in whom it was unilateral, and three were females, in one of whom it was unilateral and in two bilateral. In one female it was bilateral and very extensive, but in the other five it was slight.

In the eariy part of this year, 1936, I had a patient, Mrs. G., in my ward at the Middlesex Hospital suffering from arterial hypertension and coronary thrombosis with right branch bundle block. Opaque nerve fibres were present in the right eye, and the same abnormality was found in a sister and daughter. After much trouble all the available members of the family were examined, but it was not possible to find out whether they had any error of refraction. All appeared to be mentally normal, and there was no evidence that any had neurofibromatosis. With the exception of Mrs. G. none had any obvious defect of vision.

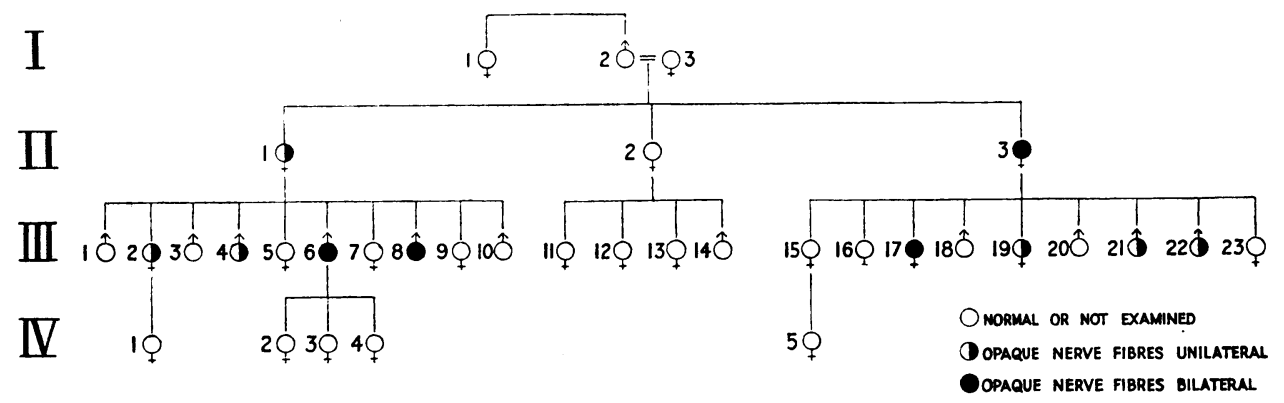

I-1. Female, aged 74 years. Incipient cataract; fundi difficult to examine, but no opaque nerve fibres seen.

$I-2$ and 3 . Dead.

II-1. Mrs. G., aged 57 years. R.V. 6/60. L.V. 6/24. Myopic fundi worse on right side. $(-3 \mathrm{D}$. Right, $-1 \mathrm{D}$. Left eye. Ring of choroidal atrophy round disc on both sides. Some arteriosclerosis. Bundle of opaque nerve fibres spreading from inner and lower quadrant of right disc.

II-2. Mrs. R. Normal.

II-3. Mrs. W. Bilateral opaque nerve fibres. Large oval patch to upper and outer side of right disc, but not actually in contact with it. From the whole of the upper and outer quadrant of the left disc opaque nerve fibres run outwards for a short distance. 
III-1. Albert G. Died aged five weeks.

III-2. Mrs. R. R., aged 38 years. Unilateral. Opaque nerve fibres at the upper border of the left disc.

III-3. Thomas G., aged 35 years. Single. Normal.

III-4. Albert G., aged 33 years. Married, no children. Unilateral. A broad splash of opaque nerve fibres arises from the upper and outer quadrant of the left disc.

III-5. Dolly G., aged 29 years. Single. Lives in France; not examined.

III-6. George G., aged 28 years. Bilateral. A small splash of opaque nerve fibres arises from upper and outer quadrant of right disc, and one arises from upper and outer and another from upper and inner quadrant of left disc

III-7. Lily G. Died, aged thirteen weeks.

III-8. Frank G., aged 22 years. Single. Bilateral. A long streak follows a vessel from the upper and outer quadrant of the right disc, a small broad splash arises from the upper and outer quadrant of the left disc.

III-9. Maud G, aged 19 years. Married, no children. Normal. III-10. James G., aged 16 years. Single. Normal.

III-11. Aged 37 years ; III-12. Aged 35 years; III-13. Aged 33 years and III-14. Aged 28 years, refused to be examined.

III-15. Mrs. F., aged 35 years. Normal.

III-16. Mrs. At., aged 33 years. Normal.

III-17. Mrs. S., aged 31 years. Bilateral. A wedge-shaped area of opaque nerve fibres covers the outer third of the right disc, a small circular patch lies near the centre of the left disc.

III-18. Harry W., aged 29 years. Single. Normal.

III-19. Mrs. Ar., aged 23 years. Unilateral. A small patch of opaque nerve fibres arising from the left disc.

III-20. William W., aged 22 years. Normal.

III-21. Frederick W., aged 21 years. Unilateral. A patch of opaque nerve fibres extends for a short distance from the outer side of the left disc.

III-22. Frank W., aged 17 years. Unilateral. A broad splash of opaque nerve fibres runs for a short distance along a vessel arising from the upper and outer quadrant of the right disc.

III-23. Caroline W., aged 13 years. Normal.

IV-1. Renée R., aged 15 years. Refused to be examined.

IV-2. Female died of pneumonia aged nine days.

IV-3. Female, aged 5 years. Normal.

IV-4. Female, aged 9 weeks. Too young to show the defect.

IV -5. Female, aged 10 years. Normal.

Kisô thinks that the gene is in the $\mathrm{X}$-chromosome and that the condition is sex-linked, on the grounds that no instance of transmission by a male occurred in his pedigree and that three females, who transmitted it, were themselves normal. He also points out that of Meyer-Riemloh's two patients the daughter had Leber's optic atrophy and that this is inherited as a sex-linked recessive in most European families. The last fact, however, affords no support to his view, because, if the optic atrophy had been a sexlinked recessive in this case, the daughter should have escaped. It is true that Waardenburg has published the pedigree of a family, in which a condition closely resembling Leber's optic atrophy was inherited as a sex-linked dominant, but in MeyerRiemloh's case the mother was normal.

Sex-linked dominants show criss-cross inheritance. Half the 
sons and half the daughters of an affected female have the defect and half are normal, but all the daughters of an affected male have the defect and all the sons are normal. Taking Kisô's pedigree into consideration, there are only two instances in which an affected male had children, and in one case the son and daughter were both normal and in the other the only child, a son, was normal. Thus there are too few sons of affected males to prove that males cannot transmit the condition to their sons.

If a defect is sex-linked and incompletely dominant, the effect of the gene for the abnormality in the X-chromosome may be suppressed in some of the females owing to the presence of the corresponding gene for normal development in the other $\mathrm{X}$ chromosome. Thus there may be some females, who appear normal, but are capable of transmitting the defect, some of the daughters of affected males may also appear to be normal, and less than half the daughters of affected females may be affected. The abnormality is also likely to be less fully developed in females than in males.

It will be seen that, though Kisô's pedigree is compatible with the condition being sex-linked and incompletely dominant, no convincing instance of criss-cross inheritance occurs in it. The fact that one well-marked example occurred with five slight ones in the same family shows that both types are determined by the same gene. This is confirmed by the observation of Jäger in one case and Terwelp in two cases that opaque nerve fibres may be extensive in one eye and slight in the other eye in the same individual. If this is accepted one would expect slight cases to occur in females and well-marked ones to be commonest in males, but Kisô's figures show that this it not so. Of 43 cases, in which the opaque nerve fibres were extensive 20 were in males and 23 in females, and of 51 , in which they were slight, 32 were in males and 19 in females. On the other hand the sex-ratio given by Kölliker and Terweip, both of whom found twice as many males as females with the defect, is in favour of sex-linkage.

The opinion expressed in the Kurzes Handbuch der Ophthalmologie, based on Kisô's pedigree, is that opaque nerve fibres in the retina are determined by an autosomal gene, which is incompletely dominant. Komai says that the material is too limited to permit a decision as to the mode of inheritance.

In the pedigree published in this paper there are 10 affected members, in 4 of whom the condition is bilateral and in 6 unilateral, and in all of them the area covered by the opaque nerve fibres is small. Five males and 5 females are affected, and in two of each sex the condition is bilateral. Of those examined in the sibships containing affected members, 10, 5 males and 5 females. are affected and 10, 4 males and 6 females are normal. Thus the 
ratio of affected to normal is $1: 1$, and descent is direct in every case. Males and females show the condition to an equal extent, and it is bilateral in the same number of females as of males, which is contrary to expectation, if it is sex-linked. It it true that there is no instance of the transmission of the abnormality by a male, but only one affected male has children, and only one of them is old enough to show the defect.

Though the pedigree does not disprove Kisô's hypothesis that the condition is sex-linked, its inheritance is quite in accord with that of an autosomal dominant, and, since autosomal dominants are common and sex-linked dominants are of extreme rarity in man, it is probable that opaque nerve fibres fall into the former rather than into the latter group. It is certain from Kisô's pedigree that the dominance is incomplete, and we have no idea what the appearance of the eyes would be in an individual homozygous for the defect.

I am indebted to Mr. R. Affleck Greeves for confirming the presence or absence of the abnormality in four of the patients, to my Registrar, Dr. E. H. Capel, for the great trouble he has taken to ensure the accuracy and, so far as possible, the completeness of the pedigree, and to Dr. A. Wilcox, Registrar, Dr. N. A. Buxton, and Dr. L. C. Bousfield for examining some of the patients.

\section{REFERENCES}

Berliner, M. L.-Arch. Ophthal., Vol. VI, p. 404, 1931.

Clausen.-Klin. Monatsbl.f. Augenheilk., Vol. LXVII, p. 116, 1921.

Fischer, H.-Derm. Zeitschr., Vol. XLII, p. 143, 1924.

Fleming, N. B. B.-Proc. Roy. Soc. Med., Vol. XIV, Sect. Ophthal., p. 22, 1921.

Hilbert, R.-Klin. Monatsbl.f. prakt. Augenheilk., Vol. XXVII, p. 141, 1889.

Johnson, G. L.-Contributions to the Comparative Anatomy of the Mammalian Eye, chiefly based on Ophthalmoscopic Examination (Phil. Trans. Roy. Soc. Lond.). London. 1901.

Kisô, K.-Arch. f. Ophthal., Vol. CXX, p. 154 (Bibliography), 1928.

Komai, Taku.-Pedigrees of Hereditary Diseases and Abnormalities found in the Japanese race. Kyoto. Pl. 80, no. 3, 1934.

Kurzes Handbuch der Ophthalmologie. Berlin. Vol. I, p. 795, 1930.

Mauthner.-Lehrbuch der Ophthalmologie. Wien. P. 355, 1868.

Meyer-Riemloh, B.-Klin. Monatsbl. f. Augenheilk., Vol. LXXIV, p. 355, 1925.

Strzeminski.-Rec. d'Ophtal., Vol. XXVIII, p. 705, 1906.

van Duyse.-Ann. d'Ocul., Vol. XCI, p. 5, 1884.

Waardenburg, P. J.-Das Menschliche Auge und sein Erbanlagen. Haag. P. 426, 1932. 